\title{
Seroprevalence and risk factors of several bovine viral diseases in dairy farms of San Pedro de los Milagros, Antioquia, Colombia ${ }^{\not}$
}

\author{
Seroprevalencia y factores de riesgo para varias enfermedades virales en \\ bovinos de hatos lecheros de San Pedro de los Milagros, Antioquia, Colombia
}

\section{Soroprevalência e fatores de risco para várias doenças virais em bovinos de rebanhos leiteiros do Município de San Pedro de los Milagros, Antioquia, Colômbia}

\begin{abstract}
Nicolás Fernando Ramírez Vásquez ${ }^{1 *}$, MV, MSc, Dr. Anim. Sci; David Villar Argaiz ${ }^{2}$, MV, PhD; Jorge Arturo Fernández Silva ${ }^{1}$, MV, MSP, Dr. Med Vet.; Julián Londoño Pino³, MV; Jenny Jovanna Chaparro Gutiérrez², MV, MSc, Dr. Sci.; Martha Eufemia Olivera Ángel ${ }^{4}$, MV, Dr Sc.Agr.
\end{abstract}

*Corresponding author: Nicolás F. Ramírez.nicolas.ramirez@udea.edu.co

${ }^{1}$ Grupo de Investigación Centauro, línea Epidemiología y Salud Pública Veterinaria, Facultad de Ciencias Agrarias, Universidad de Antioquia (UdeA). Carrera 75 N 65-87 ciudadela de Robledo.; ${ }^{2}$ Grupo de Investigación Vericel, Facultad de Ciencias Agrarias, Universidad de Antioquia; ${ }^{3}$ Empresa Colombiana de Productos Veterinarios (Vecol); ${ }^{4}$ Grupo de investigación Biogénesis, Facultad de Ciencias Agrarias, Universidad de Antioquia.

(Recibido: 5 de enero, 2016; aceptado: 8 de abril, 2016)

\section{Abstract}

Bovine viral diarrhea virus (BVDV), Bovine herpesvirus-1 (BoHV-1) and enzootic bovine leucosis (EBL) are viral infections that cause three of the most important cow diseases in the world. Antibody detection is the quickest and most cost-effective method to detect exposition to the virus. The aim of this study was to determine the seroprevalence and risk factors associated with these diseases in cows from the town of San Pedro de los Milagros, Antioquia. A total of 791 bovines of 24 dairy farms were sampled for blood between may and june of 2014, and analized for antibodies against BVDV and BoHV-1. These 24 farms plus other five were analized for antibodies against EBL for a total of 1003 bovines from 29 farms sampled. All tests were done with ELISA kits commercially available. The risk factors for farm and cow selected were evaluated to analize their relation with the serological state of these three diseases using logistic regression. In general, seroprevalence at the animal level for BVDV BoHV-1 and EBL was 75.7\% (95\% CI: 68.7-82.6\%), 31.1\% (95\% CI: 22.1-40.1\%) and 47.8\% (95\% CI: 40-55.7\%), respectively. The odds ratio of being seropositive for BoHV-1 was significantly higher $(\mathrm{OR}=3.0)$ in animals older than 3 years in comparison to bovines younger than a year. Not using disposable needles was associated with prevalence of EBL. In conclusion there was a high seroprevalence of EBL and BVDV, and a lower one for BoHV-1. Seropositivity to BoHV-1 was associated with cows older than 3 years and seropositivity to EBL was associated with not using disposable needles in the farm.

\section{Key words}

Bovine herpes virus, bovine leucosis, bovine viral diarrea virus risk factors, holstein, seroprevalence.

${ }^{\circ}$ To cite this article: Ramírez NF, Villar Argaiz D, Fernández Silva JA, Londoño Pino J, Chaparro Gutiérrez JJ, Olivera Ángel ME. Seroprevalence and risk factors for several viral diseases in bovines from dairy herds in San Pedro de los Milagros Antioquia, Colombia. Rev CES Med Zootec. 2016 ; Vol 11 (1): $15-25$. 


\section{Resumen}

Las infecciones por virus de la diarrea viral bovina (BVDV), el herpes virus bovino-1 (BoHV-1) y la leucosis enzoótica bovina (EBL) causan tres de las enfermedades más importantes de la vaca a nivel mundial. La detección de anticuerpos es el método más rápido y costo-efectivo para detectar la exposición a estos virus. El objetivo de este estudio fue determinar la seroprevalencia y los factores de riesgo asociados a estas enfermedades en vacas del municipio de San Pedro de los Milagros, Antioquia. Un total de 791 bovinos de 24 hatos lecheros no vacunados fueron muestreados para sangre entre mayo y junio de 2014 y analizados para anticuerpos contra BVDV y BoHV-1. Estos 24 hatos más otros cinco fueron analizados para anticuerpos contra EBL para un total de 1003 bovinos de 29 hatos. Todas las pruebas fueron efectuadas con kits de ELISA disponibles comercialmente. Los factores de riesgo de hato y de vaca seleccionados fueron evaluados para analizar su relación con el estado serológico de estas tres enfermedades por medio de regresión logística. En general, la seroprevalencia a nivel de animal para BVDV, BoHV-1 y EBL fue 75,7\% (95\% CI: 68,7-82,6), 31,1\% (95\% CI: 22,1-40,1) y 47,8\% (95\% CI: 40-55,7), respectivamente. La relación de disparidad de ser seropositivo para BoHV-1 fue significativamente más alto $(\mathrm{OR}=3,0)$ en animales mayores de 3 años en comparación con bovinos menores de un año. No usar agujas desechables en la granja estuvo asociada con la prevalencia a EBL. En conclusión hubo una alta seroprevalencia de EBL y BVDV y una baja para BoHV-1. La seropositividad a BoHV-1 estuvo asociada con vacas mayores a tres años y la seropositividad a EBL estuvo asociada con el no uso de agujas desechables en la granja.

\section{Palabras clave}

Factores de riesgo, herpes virus bovino, Holstein, leucosis bovina, seroprevalencia, vaca, virus de la diarrea viral bovina.

\section{Resumo}

As infecções por vírus da diarreia viral bovina (BVDV), herpes vírus bovino-1 (BoHV-1) e leucose enzoótica bovina (EBL) causam três das doenças mais importantes da vaca no mundo todo. A detecção de anticorpos é o método mais rápido e custo-efetivo para detectar a exposição a estes vírus. O objetivo desta pesquisa foi determinar a soroprevalência e os fatores de risco associados a estas doenças em vacas de diferentes rebanhos leiteiros do município de San Pedro de los Milagros, Antioquia, Colômbia. Um total de 791 bovinos pertencentes a 24 rebanhos leiteiros não vacinados foram amostrados para sangue entre os meses de maio e junho de 2014 e analisados para anticorpos contra BVDV e BoHV-1. Estes 24 rebanhos mais outros cinco foram analisados para anticorpos contra EBL para um total de 1003 bovinos de 29 rebanhos. Todos os testes foram feitos com kits de ELISA disponíveis comercialmente. Os fatores de risco do rebanho e do animal selecionados foram avaliados para analisar sua relação com o estado sorológico de estas três doenças por médio de regressão logística. Em geral, a soroprevalência no animal para BVDV, BoHV-1 e EBL foi 75,7\% (95\% CI: 68,7-82,6), 31,1\% (95\% CI: 22,1-40,1) e 47,8\% (95\% CI: 40-55,7), respetivamente. A relação de disparidade de ser soropositivo para BoHV-1 foi significativamente maior $(\mathrm{OR}=3,0)$ em animais maiores de três anos em comparação com os menores de um ano. $O$ fato de não utilizar agulhas descartáveis na fazenda, esteve associada com a prevalência a EBL. Em conclusão, houve uma alta soroprevalência de EBL e BVDV e a sua vez, uma baixa para BoHV-1. A soropositividade a BoHV-1 esteve associada com vacas maiores a três anos e a soropositividade a EBL esteve associada com a não utilização de agulhas descartáveis na fazenda.

\section{Palavras chave}

Fatores de risco, gado holandês, herpes vírus bovino, leucose bovina, soroprevalência, vaca, vírus da diarreia viral bovina.

\section{Introduction}

Herd serological profiles for major cattle disease pathogens are part of every general health monitoring program and have become essential to determine the success of control and eradication campaigns.
For example, numerous European countries are now successfully free from Enzootic Bovine Leucosis (EBL) 4 due to the implementation of measures that have gradually removed all carrier animals ${ }^{20,30}$. Regarding Infectious Bovine Rhinotracheitis (IBR), some countries in the European Union have achieved a free-status by 
implementing mandatory policies to test and dispose off seropositive animals ${ }^{11,22,26}$. To retain the status of IBR free herd, surveillance programs require that blood samples and/or bulk tank milk be tested for antibodies at regular intervals ${ }^{11}$. Similarly, for bovine viral diarrhea (BVD) a "test and cull" protocol for persistently infected (PI) individuals has been the most important control strategy, although in this case antibody screening would only provide information that BVD virus is circulating in the herd ${ }^{29}$. These strategies, together with strict biosecurity guidelines to minimize reinfection, were implemented in the early 1990s in Scandinavian and other European countries, and within a decade these countries became almost free of BVD ${ }^{28}$.

Interpretation of serological test results differs widely depending on the disease and so, proper knowledge of the pathogenesis of each disease is always necessary, as positive seroconversion may not always match with infection ${ }^{16}$. For example, in chronic diseases a positive titer may indicate presence of either an active clinical infection (Johne's disease), a carrier state (EBL and IBR) or, simply, recovery, with the animals no longer carrying the infectious agent (BVD). For a disease like EBL, seroconversion and carrier state will coexist for the animal lifetime. In diseases like BVD, vertical transmission during the first trimester of pregnancy may cause abortion or the birth of an immunotolerant PI calf. Thus, a positive antibody test for BVD virus typically means a recovered case that is no longer infectious, whereas a negative result could be either an immunotolerant PI carrier or a non-exposed individual ${ }^{16}$.

Although transiently infected BVD animals could spread the infection for a brief period of 1-2 weeks in the viremic phase, they are not considered to be important in maintaining the infection at the herd level ${ }^{35}$. By contrast, when an animal is seropositive to IBR it must be regarded as a potential source of the virus and risk to other herd mates ${ }^{36}$. The majority of infections for highly contagious diseases such as BVD and IBR are subclinical, which makes them insidious pathogens that can reach extremely high prevalence in any herd. As such, its diagnosis should be approached at the herd level. For example, a confirmed clinical case of BVD (i.e., mucosal disease or abortion) in a single animal should ideally be followed by further research at the herd level in an attempt to eliminate PI individuals that can shed vast quantities of virus and rapidly spread the infection ${ }^{35}$. In the absence of confirmed disease cases or for monitoring purposes, antibody testing of unvaccinated animals between 8 and 12 months of age can provide reliable information whether BVD is actively circulating in the population. This age is usually recommended to avoid cross-reactions with colostrum antibodies and to allow enough time to become infected by PI herd mates. In general, a high seroprevalence at herd level is indicative that the population contains a PI animal, while a largely negative herd is unlikely to contain a PI individual. Detailed procedures to control and eradicate BVD at the herd level are well illustrated in some review papers ${ }^{17}$.

There are approximately 2.5 million bovines in Antioquia, representing $11 \%$ of the entire Colombian cattle population $^{13}$. The high plains of Northern Antioquia gather the largest population of dairy cattle with about 310.000 milking cows. However, epidemiological information for the presence of major viral pathogens in the area is still missing. Recent studies in other parts of Colombia and reported in local journals and trade magazines, have shown very high individual-animal prevalence for both IBR and BVD viruses, with only a few herds negative for IBR, and with BVD always present in all farms in more animals than IBR $9,23,25,27$. Only one of the former studies attempted to provide some information on risk factors associated with seropositive animals, showing that the use of bulls, instead of artificial insemination, would increase IBR and BVD seroconversion and that the purchase of new animals also enhanced BVD prevalence ${ }^{10}$. Knowledge of risk factors is crucial in the investigation of outbreaks and to implement corrective measures, as has been shown during the final stages of eradication campaigns in some European countries ${ }^{34}$. In Europe EBL is a notifiable disease, and official control measures include screening or monitoring, precautions at borders, control of movement inside the country, and stamping out, but this is not the case in Colombia.

The present paper was part of a large health monitoring survey in one of the main dairy areas of Colombia. It describes the seroprevalence of BVDV, BoHV-1 and EBL and the risk factors associated in a representative population of dairy cattle in San Pedro de los Milagros, Antioquia, Colombia.

\section{Materials and methods}

\section{Ethical considerations}

This research was approved by the Ethics Committee for Animal Experimentation of the Universidad of Antioquia, Colombia (Act number 88, from March 27, 2014)

\section{Study area and animals}

The study was performed at 29 dairy farms between May 
and July 2014. The farms are located in the municipality of San Pedro de los Milagros, Antioquia, with a total population of 65.000 cattle, in the high Colombian tropics of Antioquia, at an altitude of $2500 \mathrm{~m}$ above sea level, on latitude $6^{\circ} 27^{\prime} 34^{\prime \prime} \mathrm{N}$ and longitude $75^{\circ} 33^{\prime} 28^{\prime \prime} \mathrm{W}$. A total of 1003 bovines (99.1\% females) of the following ages were sampled: $<1$ year and $>3$ months $(n=149)$, $1-<2$ years $(n=131), 2-<3$ years $(n=175)$ and 3 or more years $(n=548)$. The sample size for each farm, number of farms, and ages within each farm, was chosen to be proportional to the district's population of 65.000 head, with an expected prevalence of $50 \%$, margin of error of $3.1 \%(\leq 5 \%)$, and a $95 \%$ confidence interval. The cow breeds were Holstein, Jersey-Holstein, Jersey and others. The number of farms with land area of $<50,50-100$, and $>100$ "fanegas" (1 fanega $=0.66$ hectares) were 19,7 and 1 , respectively, there were no data available for land area for two herds. Six herds $(20.6 \%)$ had less than 50 cows, nine herds (31\%) had between 50-100 cows and fourteen herds $(49 \%)$ had more than 100 cows. The management system practiced in the area is primarily an intensive rotational grazing system on kikuyu (Penisetum clandestinum) monoculture pastures. No confinement of adult cows were found at any of the herds, and calves are usually kept in separate paddocks at ages between 3-9 months and then moved to replacement heifers until they are $\geq 15$ months old. Pastures are rested for approximately 30-40 days, and occupation days vary with grazing density of animals. All farms were up to date on the annual official vaccinations against brucellosis and foot and mouth disease, and 5 out of 29 farms used vaccines against viruses of the bovine respiratory complex (BVD, IBR, PI3, and BRSV). Thus, only data from the 24 non-vaccinated cattle farms were used for determining prevalence for BVD and IBR.

\section{Sample collection and serological tests}

Blood samples were collected from the coccygeal vein in vacutainer tubes with and without anticoagulant and transported to the laboratory within $12 \mathrm{~h}$. They were then centrifuged at $1500 \mathrm{x} \mathrm{g}$ for $10 \mathrm{~min}$ to obtain serum and immediately run for the presence of antibodies to BVDV, BoHV-1 and EBL. The following commercial ELISA kits were used for each virus: BVDV (SerelisaÒ BVD p80 Ab Mono blocking, Synbiotics Europe, France), BoHV-1 (SerelisaÒ BHV-1 gB Ab Mono Blocking, Synbiotics Europe, France), EBL (SerelisaÒ EBL Ab Mono Blocking, Synbiotics Europe, France).

\section{Statistical analysis}

Data was entered into Excel worksheets (Microsoft Corp., Redmond, WA, USA) and then exported to Stata
$12.0^{32}$ for analysis. Descriptive statistics were computed for most variables. An unconditional logistic regression model was constructed and the relationship between the prevalence of serological status as the dependent variable and independent variables was analyzed. Unconditional associations between each risk factor and the outcome of interest-ELISA positive-were computed. Associations with $\mathrm{p} \leq 0.25$ were retained for consideration in a multivariable model. A complete multivariable logistic regression model was constructed considering a significance level of $p<0.05$. The variables that presented less than $30 \%$ missing data or had no erroneous data and were introduced in the unconditional logistic regression model included: age, farm size, herd size, pasture leasing, trespassing of neighboring cows, use of disposable needles, and sharing of bulls between farms. The variable sex was not included in the analysis because $99.1 \%$ of the animals were female. The results are presented as odds ratios (OR) along with their 95\% confidence intervals. Those samples that fell within the suspect category for each virus were considered as negative for the purpose of the regression analysis.

\section{Case definition}

A cow was considered positive to EBL if the serum-topositive ratio was higher than 0.55 , as recommended by the manufacturer of the kit. With regards to BVDV, samples with a percentage competence $(\% \mathrm{M}) \geq 50 \%$ were considered as positive. For BoHV-1, samples with an $\mathrm{M} / \mathrm{N}$ ratio $£ 0.5$ were positive. Any farm with at least one seropositive animal was considered as positive.

\section{Risk factors}

The information on variables of interest was collected through personal interviews with questionnaires. Only variables with consistent information and few data missing were analyzed (Table 1).

\section{Results}

The results with the overall and within age seroprevalence for each virus are summarized in Table 2. For BVDV, a total of 599 out of $791(75.7 \%)$ animals were positive, with an intra-herd prevalence ranging from 17.6 to $100 \%$. A frequency distribution of the within-herd seroprevalence is presented in the Figure 1. All herds had at least one seropositive animal, 4 had a within herd prevalence of less than $51 \%$ and 20 herds had more than $50 \%$ of their animals seropositive.

For BoHV-1, a total of 246 out of 791 (31.1\%) animals were seropositive (Table 2), with an intra-herd prevalence 
Table 1. Selected cow and herd-level predictors considered as risk factors for EBL, BoHV-1 and BVDV in dairy cattle from farms in the Northern Plains of Antioquia, Colombia.

\begin{tabular}{lcccc}
\hline \multicolumn{1}{c}{ Variable } & $\begin{array}{c}\text { Unit/ } \\
\text { category }\end{array}$ & Description & $\begin{array}{c}\text { Observations } \\
\text { (no.) }\end{array}$ & $\begin{array}{c}\text { Distribution } \\
\text { (\%) }\end{array}$ \\
\hline \multirow{3}{*}{ Age category } & $<1$ y & & 149 & 14.86 \\
& $1-<2$ y & & 131 & 13.06 \\
& $2-<3$ y & & 175 & 17.45 \\
& 3 or more & & 548 & 54.64 \\
\hline \multirow{2}{*}{ sex } & Female & & 994 & 99.1 \\
& Male & & 9 & 0.9 \\
\hline \multirow{2}{*}{ Farm Size } & Small & $<50$ & 19 & 70.3 \\
(fanegas) & Medium & $50-100$ & 7 & 26.0 \\
& Large & $>100$ & 1 & 3.7 \\
\hline \multirow{2}{*}{$\begin{array}{l}\text { Herd size } \\
\text { (\# cows) }\end{array}$} & Small & $<50$ & 6 & 20.4 \\
& Medium & $>49$ and $<101$ & 9 & 31.1 \\
\hline Farms grassland & large & $>100$ & 14 & 48.9 \\
lease & Yes & & 10 & 33.6 \\
\hline External cows & No & & 19 & 66.40 \\
passing through the & Yes & & 4 & 13.36 \\
farm & No & & 25 & 86.4 \\
\hline Use of disposable & Yes & & 24 & 83.55 \\
needles & No & & 5 & 16.45 \\
\hline Sharing of bulls & Yes & & 28 & 3.19 \\
between farms & No & & & 96.8 \\
\hline
\end{tabular}

ranging between 0 and $95 \%$. A frequency distribution of the within-herd seroprevalence is presented in the figure 1. Three herds were free of seropositive animals, 15 herds had a within herd prevalence of less than $51 \%$, while six herds had a seroprevalence of more than $50 \%$.

Antibodies against EBL were detected in 480 out of 1003 animals $(47.9 \%)$ with an intra-herd prevalence ranging between 17.1 and $82.3 \%$. A frequency distribution of the within-herd seroprevalence is presented in the figure 1. All herds had at least one seropositive animal, 15 herds had prevalence of more than $51 \%$, and 14 had less than $50 \%$ of their animals infected.

\section{Prevalence for combined seropositivity}

Out of 791 cows sampled for all three viral agents, 150 (19\%) were positive to BoHV-1 and EBL, 270 (34\%) were positive to BVDV and EBL, $184(23.3 \%)$ were positive to BoHV-1 and BVDV, while $97(12.2 \%)$ were seropositive to all BVDV, BoHV-1 and EBL.

\section{Logistic Regression}

Unconditional logistic regression. In the unconditional logistic regression analysis the results varied according to the virus studied. For BVDV the variable "age group" showed a potential effect on its seroprevalence $(\mathrm{OR}=1.17$ $\mathrm{p}<0.1)$. For BoHV-1 the variables "age group" $(\mathrm{OR}=1.68$ $\mathrm{p}<0.05)$ and "sharing of bulls between farms" $(\mathrm{OR}=1.63$ $\mathrm{p}<0.05$ ) were significantly associated with the response variable, while "Neighboring cows trespassing" showed a potential effect $(\mathrm{OR}=2.58 \mathrm{p}<0.1)$.

For EBL only the variable "use of disposable needles" resulted significantly associated with the seroprevalence of that virus $(\mathrm{OR}=1.76 \mathrm{p}<0.05)$. (Table 3$)$.

Multivariable logistic regression. In the final multivariable model only variables with $\mathrm{p}<0.05$ were considered significant. No variables were associated with increased seroprevalence for BVDV.

Increased age was the only factor found to be associated with higher risk of infection for BoHV-1. The odds of being seropositive for BoHV-1 were 3.0 times higher in animals of 3 or more years of age compared with those $<1$ year old $(\mathrm{p}<0.05)$, but was not different for ages between $1-<2$ and $2-<3$ years old (Table 4 ). 
Table 2. Overall and within age seroprevalence of BVDV, BoHV-1 and EBL in dairy cattle from farms in the Northern Plains of Antioquia, Colombia.

\begin{tabular}{ccccc}
\hline Virus/Age category & $\begin{array}{c}\text { Number } \\
\text { of animals } \\
\text { tested }\end{array}$ & $\begin{array}{c}\text { Prevalence } \\
(\%)\end{array}$ & $\begin{array}{c}\text { Standard } \\
\text { Error }\end{array}$ & $\begin{array}{c}\text { 95\% Confidence } \\
\text { Intervals }\end{array}$ \\
\hline BVDV & & & & \\
$<1$ y & 112 & 70.9 & 3.5 & $62.9-78.9$ \\
$1-<2$ y & 82 & 74.7 & 6.2 & $59.4-89.9$ \\
$2-<3$ y & 147 & 67.1 & 2.9 & $60.6-73.6$ \\
3 or more y & 450 & 79.8 & 4.0 & $70.9-88.7$ \\
Overall & 791 & 75.7 & 3.1 & $68.7-82.6$ \\
BoHV-1 & & & & \\
$<1$ y & 112 & 19.2 & 6.1 & $5.3-33.0$ \\
$1-<2$ y & 82 & 12.3 & 2.8 & $5.3-19.1$ \\
$2-<3$ y & 147 & 18.7 & 5.6 & $6.0-31.7$ \\
3 or more y & 450 & 41.7 & 4.8 & $30.9-52.5$ \\
Overall & 791 & 31.1 & 4.0 & $22.1-40.1$ \\
EBL & & & & \\
$<1$ y & 149 & 46.3 & 2.6 & $40.7-51.9$ \\
$1-<2$ y & 131 & 39.7 & 3.4 & $32.0-47.2$ \\
$2-<3$ y & 175 & 42.9 & 4.7 & $32.6-53.2$ \\
3 or more y & 548 & 51.9 & 4.7 & $41.9-61.9$ \\
Overall & 1003 & 47.9 & 3.7 & $40.1-55.7$ \\
\hline
\end{tabular}

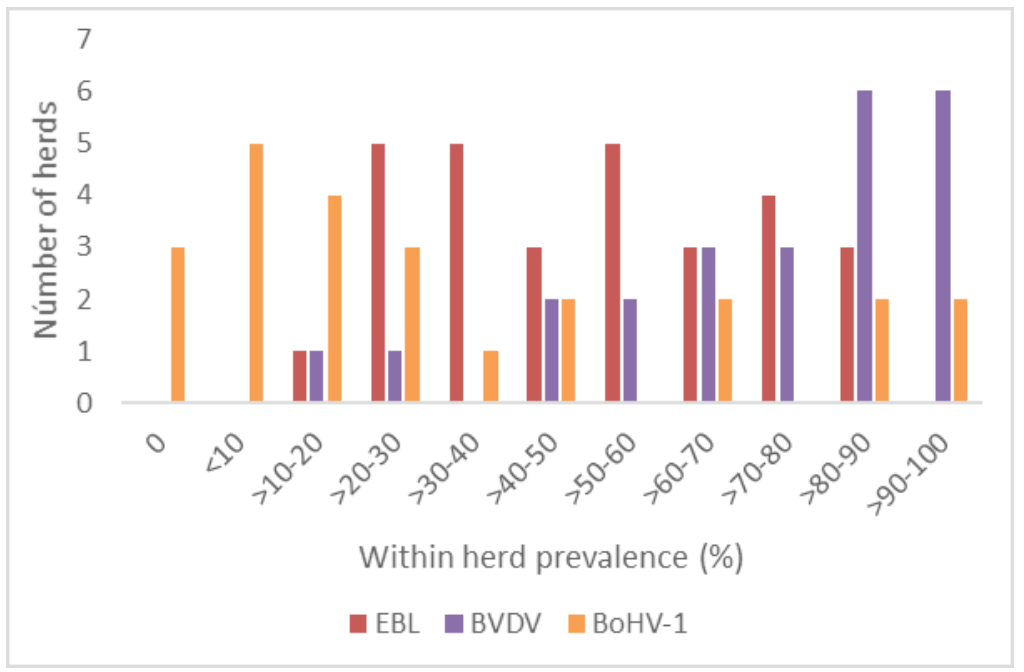

Figure 1. Frequency distribution of within-herd seroprevalence for 29 Antioquian dairy farms (EBL) and 24 Antioquian dairy farms (BoHV-1 and BVDV). 
Table 3. Results of the unconditional logistic regression analysis for the association between each variable and seroprevalence status for BVDV, BoHV-1 and EBL in dairy cattle from farms in the Northern Plains of Antioquia, Colombia.

\begin{tabular}{|c|c|c|c|c|}
\hline Virus & Variables & $O R$ & $\begin{array}{l}95 \% \text { Conf. } \\
\text { Interval }\end{array}$ & P-value \\
\hline \multirow{9}{*}{ BVDV } & Age group & 1.17 & $0.98-1.40$ & $0.064 *$ \\
\hline & Farm size & 0.63 & $0.34-1.14$ & 0.116 \\
\hline & Herd size & 0.61 & $0.27-1.37$ & 0.209 \\
\hline & Pasture leasing & 0.59 & $0.23-1.49$ & 0.235 \\
\hline & $\begin{array}{l}\text { Neighboring cows } \\
\text { trespassing }\end{array}$ & 1.79 & $0.46-6.95$ & 0.359 \\
\hline & $\begin{array}{l}\text { sharing of bulls between } \\
\text { farms }\end{array}$ & 1.03 & $0.70-1.53$ & 0.838 \\
\hline & Age group & 1.68 & $1.36-2.07$ & $0.000 * *$ \\
\hline & Farm size & 0.63 & $0.29-1.32$ & 0.192 \\
\hline & Herd size & 0.84 & $0.60-1.19$ & 0.307 \\
\hline BoHV-1 & Pasture leasing & 1.18 & $0.27-5.27$ & 0.80 \\
\hline \multirow{8}{*}{ EBL } & \multirow{8}{*}{$\begin{array}{l}\text { Neighboring cows } \\
\text { trespassing } \\
\text { sharing of bulls between } \\
\text { farms } \\
\text { Age group } \\
\text { Farm size } \\
\text { Herd size } \\
\text { Pasture leasing } \\
\text { Neighboring cows } \\
\text { trespassing } \\
\text { use of disposable needles }\end{array}$} & 2.58 & $0.82-8.03$ & $0.093 *$ \\
\hline & & 1.63 & $1.05-2.53$ & $0.031 * *$ \\
\hline & & 1.12 & $0.96-1.31$ & 0.113 \\
\hline & & 1.28 & $0.75-2.21$ & 0.339 \\
\hline & & 1.09 & $0.75-1.56$ & 0.619 \\
\hline & & 1.01 & $0.51-1.99$ & 0.973 \\
\hline & & 0.69 & $0.25-1.86$ & 0.44 \\
\hline & & 1.76 & $1.09-2.85$ & $0.023 * *$ \\
\hline
\end{tabular}

Table 4. Final logistic-regression model for risk factors associated with seroprevalence to BoHV-1 and EBL in dairy cattle of the northern plains of Antioquia, Colombia.

\begin{tabular}{ccccc}
\hline & OR & $\begin{array}{c}\text { Standard } \\
\text { Error }\end{array}$ & $\begin{array}{c}\text { 95\% confidence } \\
\text { intervals }\end{array}$ & P value \\
\hline $\begin{array}{c}\text { BoHV-1 } \\
\text { Age (years)* }\end{array}$ & & & \\
$<1$ & - & - & - & - \\
$1-<2$ & 0.59 & 0.16 & $0.32-1.09$ & 0.08 \\
$2-<3$ & 0.98 & 0.53 & $0.28-3.30$ & 0.95 \\
$\begin{array}{c}3 \text { or more } \\
\text { EBL }\end{array}$ & 3.01 & 0.82 & $1.64-5.52$ & $0.00^{*}$ \\
$\begin{array}{c}\text { use of disposable } \\
\text { needles }\end{array}$ & 1.76 & 0.4 & & \\
\hline & & & \\
& & & & \\
& & & &
\end{tabular}


For EBL only the use of disposable needles was found to be associated with EBL seroprevalence. The odds of being seropositive to EBL is 1.76 times higher in farms not using disposable needles compared with herds that use disposable needles $(\mathrm{p}<0.05)$.

\section{Discussion}

The results showed very high prevalence of antibodies to BVDV (75.7\%), which were higher than those reported in other Colombian areas of $58 \%$ and $51.9 \%$ found by Motta et al., (2013) ${ }^{21}$, 55.1\% by Cruz et al., (2014) ${ }^{12}, 46 \%$ by Peña L, (2001) ${ }^{24}, 32.7 \%$ by Cedeño et al., (2011) ${ }^{10}$ and $29.5 \%$ by Betancur et al., (2007) ${ }^{6}$. The prevalence reported here for BoHV-1 was not as high as that reported in other works of $94 \%$ by Motta et al., (2013) ${ }^{21}, 74.4 \%$ by Betancur et al., (2006) ${ }^{7}, 55.5 \%$ by Piedrahita et al., $2010^{25}$, 85,5\% by Ruiz-Saenz et al., (2010) ${ }^{27}$ and $69,8 \%$ by Ochoa et al., (2012) ${ }^{23}$. Only one Colombian study reported a lower seroprevalence of IBR of $17.6 \%{ }^{10}$. Regarding EBL, the prevalence found here $(47.9 \%)$ was lower than that reported by Carrero et al., (2009) ${ }^{8}$ of $73 \%$ and higher than the $19.8 \%$ reported by Benavides et al., (2013) ${ }^{5}$. Differences between these results could be explained for the different characteristics of the studies like locations, cattle breeds, management, sample strategies and the use of different ELISA kits.

In spite of the high seroprevalences observed for these viruses, there are no Governmental policies to the control and eradication of these diseases. None of these viruses are considered within the list of notifiable diseases in Colombia and there are currently no control measures to prevent their dissemination. However, it is clear from studies in countries that have eradicated BVD or are in the process of doing so, that the annual benefits of eradication campaigns far exceed their cost by factors of 5 to 14 for the beef and dairy sectors, respectively ${ }^{33,34}$. Unfortunately, because the benefits of eradicating BVD and IBR are based on hidden losses that will perpetuate in the absence of control measures, in our case it is unlikely that anybody will incur on the costs of starting such campaigns.

This study found combined seropositivity, it means that some cows showed ELISA positive results to more than one virus. This result could be explained due that both BVDV and BoHV-1 have very similar routes of transmission and so are the risk management practices for their control. However for these practices to be efficient, they would have to be applied systematically and continuously at regional or national level, and not just in individual herds.
For BVD, control and eradication programs in European countries have been largely based on test and cull schemes that target PI animals and establish strict biosecurity measures to prevent re-infection ${ }^{17,28}$. In areas that had very high BVD seroprevalence, like those observed in this study, and where cattle density was high and so was undocumented (about BVD) animal trafficking, herds clearing the infection were obviously at higher risk of reinfection from losing immune protection and becoming naïve to the virus. In those situations it has been shown that vaccination, combined with removal of PI animals, would overcome the problem of reinfection by preventing intrauterine infection in pregnant dams at risk of exposure to contact with undetected PI animals 14,19 .

However, vaccination alone has not been sufficient to remove BVD from every herd and so the identification and elimination of PI animals, even before vaccination, remains indispensable. This has been long recognized in the USA, where despite decades of vaccinations, BVD continues to be a major problem.

In addition, for the success of eradication campaigns against BVD and IBR the studies in Europe have also highlighted the importance of restricting the movement of cattle between herds, and particularly infected animals or using semen for artificial insemination from an infected bull. Needless to say that the success of systematic control programs have required a strong collaboration between government, veterinarians and farmers.

Control measures in IBR eradication programs in some European countries include bans on: purchasing positive animals, use of whole-virus vaccines that prevent differentiating infected from vaccinated animals and, inseminating cows with semen from positive bulls ${ }^{11}$. The use of marker/DIVA (Differentiating Infected from Vaccinated) vaccines, together with culling of seropositive animals, has been the primary strategy of control and eradication campaigns because it allows differentiating infected from vaccinated animals. However, the use of vaccines has some limitations and even when they have been successful in significantly reducing the transmission and incidence of disease, they will not prevent infection from wild-type viruses, and so, outbreaks could always occur if vaccination is stopped ${ }^{2}$. Consequently, even if vaccines can be a great advantage when seroprevalence is high, as in the initial stages of controlling IBR, if eradication is the ultimate goal there will be a point in which apparently healthy but seropositive animals will need to be removed. 
In the final multivariable model no variables were associated with increased seroprevalence for BVDV the reason why no effects were observed for any herd variables in the logistic regression model was probably related to lack of negative herds. Age was not found to be associated with BVD prevalence but was positively related to IBR. A possible explanation for this result was the high BVD prevalence in most farms that could have easily precluded seeing significant differences between them. It would be important to categorize in order of importance the risk factors on a farm to farm basis, as the actual weight of each one is likely very different. In Colombia, and particularly with small scale dairy farmers in our area, cattle are not quarantined, are traded with no health certificates, and rarely are sick animals separated from healthy mates. Thus, a major education campaign would be paramount to lead any further actions to control these viral diseases.

Some essential risk factors that have been found to increase seroprevalence for IBR and BVD are aspects that are still beyond the control of individual farmers in Colombia. For example, introducing new cattle in the farm should be accompanied by testing these animals for BVDV-viremia in order to avoid the introduction of the virus; these are diagnostic tests that are still not available to the Colombian farmer. In general, some of the common risk factors for increased seroprevalence that are typically recognized for either BVD and IBR or both, include: over the fence direct contact, different herds sharing common pasture grounds (communal grazing), livestock trade that involves purchasing transiently or persistently infected cattle, bull leasing 18,22,31. Although older age and herd size are probably the two most common factors that are always mentioned to be associated with BVD and IBR in most surveys, they should probably be considered to be a result of the presence of the viruses rather than a risk factor for seropositivity. Furthermore, these are also the easiest ones to record most reliably in any questionnaire. In this study and contrary to expectations, age and herd size were factors that showed small or no effects.

The only variable that had a significant effect for EBL seroprevalence was not using disposable needles in the farm, this is in accordance with the findings of Alfonso et al., (1998) ${ }^{3}$ who reported a cow-level seroprevalence near $50 \%$ and also related several risk factors with increased odds of finding seropositive animals, such as: not changing obstetrical sleeves to palpate, and practice of purchasing animals from outside sources without a serological screen for EBL (Alfonso et al. 1998) ${ }^{3}$. Some countries have managed to drastically reduce and/ or eradicate the disease by implementation of control measures that involve complete separation of EBL positive from negative animals ${ }^{1}$. Individual herds have also succeeded in rapidly reducing the seroprevalence within a few years when physical separation of positive animals was implemented, in addition to sanitary measures to minimize iatrogenic transmission ${ }^{15}$.

\section{Conclusions}

There was a high seroprevalence of EBL and BVDV and lower for BoHV-1. Increased BoHV-1 seropositivity was associated with cows older than three years old, EBL seropositivity was associated with not using disposable needles in the farm. Future studies should focus on doing economic assessments of the benefits (less disease losses) and costs (testing and culling) of potential eradication programs to the Colombian dairy sector. Proving there is a high benefit-cost ratio would be highly desirable to encourage the different stakeholders of the cattle industry to coordinate an eradication campaign.

\section{Acknowledgements}

The authors are grateful to Empresa Colombiana de Productos Veterinarios (VECOL) and Universidad de Antioquia for co-financing the present study. To Diego Ortiz (Corpoica), Yanira Chaparro (Zoolab), Julio Tobón and Alfredo Sánchez (VECOL) for their cooperation. The authors also thank the Sustainability Project, Centauro 2013-2014 (Estrategia de Sostenibilidad Centauro CODI 2013-2014, Universidad de Antioquia) and Sustainability Project to Biogenesis 2014-2015.

Conflict of interest statement: The manuscript was prepared and reviewed with the participation of all the authors, who declare that there is no conflict of interests that jeopardize the validity of the results presented.

\section{References}

1. Acaite J, Tamosiunas V, Lukauskas K, Milius J, Pieskus J. The eradication experience of enzootic bovine leukosis from Lithuania. Prev Vet Med 2007;82(1-2):83-9.

2. Ackermann M, Engels M. Pro and contra IBR-eradication. Vet Microbiol 2006;113(3-4 SPEC. ISS.):293-302.

3. Alfonso R, Almansa JE, Barrera J. Serological prevalence and evaluation of risk factors of enzootic bovine leukosis in the Sabana de Bogota region and the Ubate and Chiquinquira Valleys of Colombia. Rev Sci Tec Off Int Epiz 1998;17(3):723-732. 
4. Annual report of European Union on bovine and swine diseases, 2012. Chapter 2 Enzootic Bovine Leukosis. 2012 [accessed 2015 May 15]. http:// ec.europa.eu/food/animal/liveanimals/bovine/docs/ final_report_2012_en.pdf

5. Benavides B, Cedeño DA, Serrano MF. Epidemiological study of bovine leukemia virus in dairy cows in six herds in the municipality of Pasto, Nariño. Rev Lasallista Invest 2013;10(1):18-23.

6. BetancurC, GogorzaL,MartínezF. Seroepidemiología de la diarrea viral bovina en Montería (Córdoba, Colombia). Analecta Vet 2007;5(11):6-11.

7. Betancur C, González M, Reza L. Seroepidemiología de la rinotraqueitis infecciosa bovina en el Municipio de Montería, Colombia. Rev MVZ Córdoba 2006;11(2):830-836.

8. Carrero J, Martínez F, Tarazona A, Cepeda B. Prevalencia de seropositividad a leucosis bovina mediante la técnica diagnóstica de Elisa indirecta en hatos lecheros situados en Mesa de los Santos, Santander. Spei Domus 2014;5(11):6-11.

9. Carrillo A, Moreno-Figueredo G, González-Medrano $\mathrm{K}$, Martínez Contreras J. Determining the presence of antibodies to Neospora caninum and bovine viral diarrhea virus and its relationship to the reproductive performance of bovine females of Oicata - Boyacá. Rev CES Med Vet y Zootec 2014;9:2.

10. Cedeño D, Benavides B, Cárdenas G, Herrera C. Seroprevalence and risk factors associated to BHV-1 and DVBV in dairy herds in Pasto, Colombia, in 2011. Rev Lasallista Investig 2011;8(2):61-68.

11. Comission of the European communities. Comission Decision. 2014 [accessed 2015 Apr 4]:1-9.http:// www.pvd.gov.lv/uploaded_files/Majas_lapa_2/ Veterinara_uzraudziba/EK Lemums 2004_558_EK (rinotraheits).pdf

12. Cruz A, Moreno G, González K, Martínez J. Determinación de la presencia de anticuerpos contra Neospora caninum y el virus de la diarrea viral bovina y su relación con el desempeño reproductivo de hembras bovinas del municipio de Oicatá (Boyacá). Rev CES Med Vet y Zootec.2014;9(2):238-247.

13. DANE. Oferta Agropecuaria: ENA 2011. 2011. [accessed 2015 Apr 4]: http://formularios.dane.gov. co/Anda_4_1/index.php/catalog/25/export
14. Graham D, Clegg T, Lynch M, More S. Herd-level factors associated with the presence of bovine viral diarrea in herds participating in the voluntary phase of the Irish national eradication program. Prev Vet Med 2013;112:99-108.

15. Johnson R, Gibson CD, Kaneene JB. Bovine leukemia virus: A herd-based control strategy. Prev Vet Med 1985;3(4):339-349.

16. Lanyon SR, Hill FI, Reichel MP, Brownlie J. Bovine viral diarrhoea: pathogenesis and diagnosis. Vet J 2014;199(2):201-9.

17. Laureyns J, Ribbens S, de Kruif A. Control of bovine virus diarrhoea at the herd level: Reducing the risk of false negatives in the detection of persistently infected cattle. Vet J 2010;184(1):21-26.

18. Mainar-Jaime RC, Berzal-Herranz B, Arias P, RojoVázquez FA. Epidemiological pattern and risk factors associated with bovine viral-diarrhoea virus (BVDV) infection in a non-vaccinated dairy-cattle population from the Asturias region of Spain. Prev Vet Med 2001;52:63-73.

19. Moennig V, Eicken K, Flebbe U, Frey HR, Grummer B, Haas L, Greiser-Wilke I, Liess B. Implementation of two-step vaccination in the control of bovine viral diarrhoea (BVD). Prev Vet Med 2005;72(1-2):109-114.

20. Molloy JB, Dimmock CK, Eaves FW, Bruyeres AG, Cowley JA, Ward WH. Control of bovine leukaemia virus transmission by selective culling of infected cattle on the basis of viral antigen expression in lymphocyte cultures. Vet Microbiol 1994;39(34):323-333.

21. Motta J, Waltero I, Abeledo M. Prevalencia de anticuerpos al virus de la diarrhea viral bovina, Herpesvirus bovino 1 y Herpesvirus bovino 4 en bovinos y búfalos en el departamento de Caquetá Colombia. Rev Salud Anim 2008;35(3):174-181.

22. Nardelli S, Farina G, Lucchini R, Valorz C, Moresco A, Dal Zotto R, Costanzi C. Dynamics of infection and immunity in a dairy cattle population undergoing an eradication programme for Infectious Bovine Rhinotracheitis (IBR). Prev Vet Med 2008;85(12):68-80.

23. Ochoa X, Orbegozo M, Manrique-Abril F, Pulido M, Ospina J. Seroprelavence of infectious bovine rhinotrecheitis in dairy herds of Toca - Boyacá. Rev MVZ Córdoba 2012;17(2):2974-2982. 
24. Peña L. Estudio serológico de diarrea viral bovina en la microrregión del Valle del Cesar. AICA 2011;1:309-312.

25. Piedrahita L, Montoya L, Pedraza F. Bovine herpes virus type- 1 as a possible cause of encephalitis in cattle of the Colombian Magdalena Medio region. Serological study and epidemiological analysis. Rev Colomb Ciencias Pecu 2010;23:191-198.

26. Raaperi K, Orro T, Viltrop A. Epidemiology and control of bovine herpesvirus 1 infection in Europe. Vet J 2014;201(3):249-56.

27. Ruiz Sáenz J, Jaime J, Vera V. Prevalencia serológica y aislamiento del Herpesvirus Bovino-1 (BHV-1) en hatos ganaderos de Antioquia y del Valle del Cauca. Rev Colomb Cienc Pecu 2010;23(3):299-307.

28. Sandvik T. Progress of control and prevention programs for bovine viral diarrhea virus in Europe. Vet Clin North Am Food Anim Pract 2004;20(1):15169.

29. Sayers RG, Byrne N, O'Doherty E, Arkins S. Prevalence of exposure to bovine viral diarrhoea virus (BVDV) and bovine herpesvirus-1 (BoHV-1) in Irish dairy herds. Res Vet Sci 2015;100:21-30.

30. Shettigara P, Samagh B, Lobinowich E. Control of bovine leukemia virus infection in dairy herds by agar gel immunodiffusion test and segregation of reactors. Can J Vet Res 1989;53(1):108-110.
31. Solis-Calderon JJ, Segura-Correa VM, SeguraCorrea JC, Alvarado-Islas A. Seroprevalence of and risk factors for infectious bovine rhinotracheitis in beef cattle herds of Yucatan, Mexico. Prev Vet Med 2003;57:199-208.

32. STATACORP. Stata Statistical Software. Release 12. StataCorp LP, College Station, TX. 2012.

33. Stott AW, Humphry RW, Gunn GJ, Higgins I, Hennessy T, O'Flaherty J, Graham D a. Predicted costs and benefits of eradicating BVDV from Ireland. Ir Vet J 2012;65(1):12.

34. Valle PS, Martin SW, Tremblay R, Bateman K. Factors associated with being a bovine-virus diarrhoea (BVD) seropositive dairy herd in the More and Romsdal County of Norway. Prev Vet Med 1999;40(3-4):165-177.

35. Walz P. Diseases Caused by Bovine Virus Diarrhea Virus. In: Large Anim Intern Med 2015. p. 750-759.

36. Woolums A. The Bronchopneumonias (Respiratory Disease Complex of Cattle, Sheep and Goats). In: Large Anim Intern Med 2015. p. 584-587. 